\title{
OCCURRENCE OF GRAM-NEGATIVE BACTERIA IN COCKROACHES COLLECTED FROM DIFFERENT AREAS OF DHAKA CITY
}

\author{
Tangin Akter*, Sangita Ahmed ${ }^{1}$ and Hasanuzzaman \\ Department of Zoology, University of Dhaka, \\ Dhaka-1000, Bangladesh
}

\begin{abstract}
The presence of Gram-negative bacteria in cuticle and alimentary tract of cockroaches collected from four selected areas of Dhaka city was investigated. Using detection key, a total of 12 cockroaches were identified as Periplaneta americana (58.33\%), Blattella germanica (33.33\%) and Blatta orientalis $(8.33 \%)$. From these three species 54 different bacterial isolates were obtained. Out of them, 33 were obtained from P. americana (14 from external and 19 from gut), 9 from $B$. orientalis ( 5 from external and 4 from gut) and 12 from $B$. germanica ( 5 from external and 7 from gut). Bacterial isolates obtained from external surface of the cockroaches belonged to four different Gram negative bacterial species (Klebsiella spp., Pseudomonas spp., Enterobacter spp. and E. coli), six bacteria have been obtained from alimentary tract (Klebsiella spp, Pseudomonas spp., Enterobacter spp., Escherichia coli, Salmonella spp. and Shigella spp.). Pseudomonas spp. were the most predominant bacteria isolated from external surface $(33.34 \%)$ while Klebsiella spp. were found to dominate in alimentary tract $(23.33 \%)$. P. americana carried the highest number (33) of bacterial isolates and $B$. orientalis carried the minimum (9). This study shows that cockroaches carry several bacteria on their external body surface and alimentary tract and can play a role in bacterial transmission to humans. Therefore, the existence of cockroaches in human dwellings is a serious public health problem.
\end{abstract}

Key words: Cockroaches, Gram-negative bacteria, Dhaka city

\section{INTRODUCTION}

Cockroaches (Blattidae, Orthoptera) are among the medically important pests in urban environment that cause serious public health problem (Cloarec et al. 1992). They are highly prevalent in residents, restaurants, medical and financial institutions, particularly in areas with unsanitary and insalubrious conditions and are often found in intimate association with human beings (Oothuman et al. 1989, Boase 1999, Hamid and Shahnaz 2012). They spread filth and ruin food and their chewing type of feeding mechanism and filthy breeding habits make them efficient vectors and transmitters of several potential pathogens (Gupta 1997).

Cockroaches have been found to harbour diverse pathogenic bacteria, different protozoa, pathogenic worms, fungi and viruses on either the cuticle or in the gut (Cloarec et al. 1992, Khrustalyova 1994). They can carry up to 14 million bacteria on the body and 7 million in each of their fecal droppings

*Author for correspondence: <aktertl@yahoo.com> 1Department of Microbiology, University of Dhaka, Dhaka-1000, Bangladesh.

(c) 2016 Zoological Society of Bangladesh DOI: 10.3329/bjz.v44i2.32762 
(Bennett 1993). Human pathogens like Salmonella typhi, Shigella dysenteriae and toxigenic strains of Escherichia coli can be retained in the gut of cockroaches for up to several days (Stek 1982).

Studies have shown that of the 25 different species of medically important bacteria isolated from Blattella germanica and Periplaneta americana collected from public hospitals and a residential house in central Tehran, Iran, Klebsiella spp. were the predominant bacteria (Tilahun et al. 2012)

Climatic condition of Bangladesh is very favorable for the survival of cockroaches. In urban areas the density of population is high and this gives poor hygienic condition, allowing cockroaches to infest every premises. Out of 13 different species of cockroaches, only three species (Periplaneta americana, Blatta orientalis and Blattella germanica) are commonly found in houses, offices and restaurants in Bangladesh (Safe Way Pest Control 2011).

Despite the abundance of cockroaches in different localities of Dhaka city, there is scanty information about their role as mechanical transmitters of pathogenic bacteria. This study therefore aims at investigating the carriage of Gram-negative bacteria in cockroaches collected from Dhaka city.

\section{MATERIAL AND METHODS}

The study was conducted in Entomology Laboratory, Department of Zoology and Microbiology Laboratory, Department of Microbiology, University of Dhaka. For the collection of the cockroaches four selective locations were chosen. The locations were: 1 No. Mess and Bikalpa Mess of Shahidullah Hall, Dining hall of Fazlul Huq Muslim Hall and Dhaka Medical College Hospital, Dhaka, Bangladesh.

Cockroaches were collected by traps and hand picking using sterile handgloves (Paul et al. 1992). Trap was made by disposable plastic bottles and lures. Collected cockroaches were placed into sterile tubes individually. These tubes were transferred to laboratory immediately after capturing and the cockroaches were killed by using chloroform. The identification of cockroach was done according to Imms (1965), Borror et al. (1981) and Kabir et al. (1981).

Isolation and identification of Gram-negative bacteria from cockroach samples: The external body surface of the cockroaches was washed using $5 \mathrm{ml}$ sterile physiological saline for two minutes, and the wash was taken as external body homogenate sample. After external body washing, the cockroaches were soaked in $90 \%$ ethanol for 5 minutes to decontaminate their external surfaces and dried, followed by washing with sterile saline to remove traces of ethanol. The alimentary tract of cockroach was aseptically dissected out using sterile 
entomological dissecting needles under a dissecting microscope. The instrument was dipped in ethanol and flamed between dissections. The excised gut was homogenized in $5 \mathrm{ml}$ of sterile normal saline water (Tachbele et al. 2006).

A total of 24 samples consisting of 12 external body surface and 12 gut homogenates were analyzed. All the collected homogenate samples were inoculated by using spread plate technique onto MacConkey agar, xylose lysine deoxycholate agar (XLD), eosin methylene blue agar (EMB), the selective media used for isolation of common pathogenic Gram-negative bacteria. Growths on all plates were observed and the morphological characteristics of colonies (size, shape, elevation, color, consistency, opacity, pigmentation) were noted. Then isolated colonies were sub-cultured into nutrient agar medium.

Gram staining was made to determine the size, shape, arrangement and Gram reaction of the isolated organisms according to the method described by Pelczar et al. (1993). The identification of the isolates was done by performing various biochemical tests, which included indole test, citrate utilization test, Kligler's iron agar (KIA) test, motility, indole, urease (MIU) test. All the tests were performed according to the standard protocol as described in Bergey's Manual of Systematic Bacteriology (2001).

\section{RESULTS AND DISCUSSION}

A total of 12 cockroaches were collected and examined for their bacteriological quality. Out of them $58.33 \%$ was Periplaneta americana, 33.33\% Blattella germanica and $8.33 \%$ was Blatta orientalis (Fig. 1). The maximum numbers of cockroaches were collected from Bikalpa Mess, Shahidullah Hall (33.33\%) and the minimum were collected from Dining hall, Fazlul Huq Muslim Hall (16.67\%) (Table 1). Periplaneta americana and Blattella germanica were isolated in larger numbers. This is in conformity with the results of Zarchi et al. (2009) who reported Periplaneta americana and Blattella germanica as the most active cockroaches in hospitals of Tehran city, Iran. Also, in a research conducted by Pai et al. (2005) in China, Periplaneta americana and Blattella germanica were isolated as the most common species.

A total number of 54 bacterial isolates were obtained from external body surface and alimentary tract homogenates of 12 cockroaches enrolled in the study. Based on the cultural, morphological and biochemical tests the isolates were presumptively identified as Klebsiella spp. 14 (26\%), 13 Pseudomonas spp. (24\%), Enterobacter spp. 11 (20\%), E. coli 9 (17\%), Salmonella spp. $4(7 \%)$ and Shigella spp. 3 (6\%) (Table 2, Figs 2, 3). Out of 54 bacterial isolates, 33 were obtained from $P$. americana (14 from external and 19 from gut), 9 from $B$. orientalis ( 5 from external and 4 from gut) and 12 from $B$. germanica (5 from 
external and 7 from gut) (Table 3). Alimentary tract and external surface samples yielded 30 and 24 isolates, respectively.

Percentage of the cockroach species

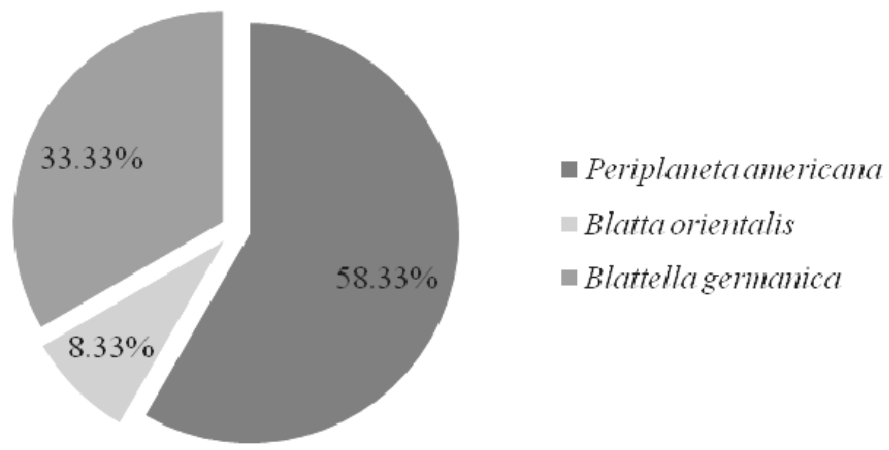

Fig. 1. Percentage of the cockroach species collected from the study areas.

Table 1. Distribution of cockroaches in study areas

\begin{tabular}{|c|c|c|c|c|c|c|c|c|}
\hline \multirow{2}{*}{$\begin{array}{l}\text { Study } \\
\text { area }\end{array}$} & \multicolumn{2}{|c|}{$\begin{array}{c}\text { Periplaneta } \\
\text { americana }\end{array}$} & \multicolumn{2}{|c|}{$\begin{array}{c}\text { Blatta } \\
\text { orientalis }\end{array}$} & \multicolumn{2}{|c|}{$\begin{array}{c}\text { Blattella } \\
\text { germanica }\end{array}$} & \multicolumn{2}{|l|}{ Total } \\
\hline & Number & $\%$ & Number & $\%$ & Number & $\%$ & Number & $\%$ \\
\hline 1 No. Mess, SH & 3 & 42.86 & 0 & 0 & 0 & 0 & 3 & 25 \\
\hline Bikalpa Mess, SH & 2 & 28.57 & 1 & 100 & 1 & 25 & 4 & 33.33 \\
\hline Dining hall, FH & 2 & 28.57 & 0 & 0 & 0 & 0 & 2 & 16.67 \\
\hline $\mathrm{DMCH}$ & 0 & 0 & 0 & 0 & 3 & 75 & 3 & 25 \\
\hline Total & 7 & 100 & 1 & 100 & 4 & 100 & 12 & 100 \\
\hline
\end{tabular}

The most predominant species of bacteria obtained from external surface of cockroaches in this study was Pseudomonas spp. (33.34\%), and the least dominant was E. coli (16.67\%). In the alimentary tract, Klebsiella spp. (23.33\%) was most frequently isolated while Shigella spp. was least frequent (10.0\%) (Table 4). These Gram-negative bacilli have been most frequently isolated from cockroaches in several other studies (Fotedar et al. 1991, Cloarec et al. 1992; Rivault et al. 1993). Lin et al. (2008) reported isolation of E. coli, Pseudomonas sp., Salmonella sp. and Enterobacter sp. from cockroaches.

Among six bacterial isolates, Klebsiella and Enterobacter were isolated in highest numbers from cockroaches trapped from Bikalapa Mess of Shahidullah Hall, as compared with the others. The dominant species obtained from DMCH were E. coli and Pseudomonas (Fig. 4). 
Table 2. Biochemical tests for presumptive identification of bacterial isolates

\begin{tabular}{|c|c|c|c|c|c|c|c|c|}
\hline \multirow{2}{*}{$\begin{array}{l}\text { Isolate } \\
\text { No. }\end{array}$} & \multicolumn{7}{|c|}{ Kligler's Iron Agar test } & \multirow{2}{*}{$\begin{array}{l}\text { Presumptive } \\
\text { organism }\end{array}$} \\
\hline & $\begin{array}{l}\text { Lac- } \\
\text { tose }\end{array}$ & $\begin{array}{l}\text { Glu- } \\
\text { cose }\end{array}$ & Gas & $\mathrm{H}_{2} \mathrm{~S}$ & $\begin{array}{l}\text { Citrate } \\
\text { use }\end{array}$ & $\begin{array}{l}\text { Urease } \\
\text { activity }\end{array}$ & $\begin{array}{l}\text { Indole } \\
\text { production }\end{array}$ & \\
\hline $\begin{array}{l}\mathrm{C} 1,5,15,24,25,39 \\
47,50,53\end{array}$ & + & + & + & - & - & - & + & E. coli \\
\hline $\begin{array}{l}\mathrm{C} 2,3,7,12,20,21, \\
22,23,27,33,34, \\
36,54\end{array}$ & - & - & - & - & + & - & - & $\begin{array}{l}\text { Pseudomonas } \\
\text { sp. }\end{array}$ \\
\hline $\begin{array}{l}C 4,6,10,13,14,17 \\
19,26,28,35,37, \\
40,44,45\end{array}$ & - & + & + & - & + & + & - & Klebsiella sp. \\
\hline $\begin{array}{l}\mathrm{C} 8,9,11,16,18.30 \\
31,32,38,42,49\end{array}$ & - & + & + & - & + & - & - & Enterobacter sp. \\
\hline $\mathrm{C} 29,43.46 .51$ & - & + & - & + & + & + & - & Salmonella sp. \\
\hline C 41,48 & - & + & - & - & - & - & + & Shigella sp. \\
\hline
\end{tabular}

Table 3. Distribution of pathogens isolated from different cockroach species

\begin{tabular}{|c|c|c|c|c|c|c|c|c|c|c|}
\hline \multirow[t]{2}{*}{ Isolate } & \multicolumn{3}{|c|}{ Periplaneta americana } & \multicolumn{3}{|c|}{ Blatta orientalis } & \multicolumn{3}{|c|}{ Blattella germanica } & \multirow[t]{2}{*}{ Total } \\
\hline & External & Gut & Total & External & Gut & Total & External & Gut & Total & \\
\hline Klebsiella & 4 & 6 & 10 & 2 & 1 & 3 & 1 & 0 & 1 & 14 \\
\hline Pseudomonas & 5 & 4 & 9 & 1 & 0 & 1 & 2 & 1 & 3 & 13 \\
\hline Enterobacter & 3 & 4 & 7 & 1 & 1 & 2 & 1 & 1 & 2 & 11 \\
\hline E. coli & 2 & 3 & 5 & 1 & 0 & 1 & 1 & 2 & 3 & 9 \\
\hline Salmonella & 0 & 1 & 1 & 0 & 1 & 1 & 0 & 2 & 2 & 4 \\
\hline Shigella & 0 & 1 & 1 & 0 & 1 & 1 & 0 & 1 & 1 & 3 \\
\hline Total & 14 & 19 & 33 & 5 & 4 & 9 & 5 & 7 & 12 & 54 \\
\hline
\end{tabular}

Table 4. The frequency of bacteria species isolated from cockroaches external surface and alimentary tract

\begin{tabular}{lcc}
\hline Bacterial spp. & External surface (\%) & Digestive organ (\%) \\
\hline Klebsiella sp. & 29.17 & 23.33 \\
Pseudomonas sp. & 33.33 & 16.67 \\
Enterobacter sp. & 20.83 & 20.0 \\
E. coli & 16.67 & 16.67 \\
Salmonella sp. & 0 & 13.33 \\
Shigella sp. & 0 & 10.0 \\
\hline
\end{tabular}

Most of the bacteria isolated are clinically important and associated with diseases in humans. The pathogenicity of these isolates can be further confirmed by detecting presence of specific virulence genes. These findings agree with the results of other investigations which showed that these bacterial 
species on cockroaches collected from hospitals and food handling establishments (Bennett 1993, Chaichanawongsaroj et al. 2004, Salehzadeh et al. 2007). Zarchi and Vatani (2009) also detected E. coli, Streptococus and Bacillus as the most isolated bacteria from the hospital cockroaches.

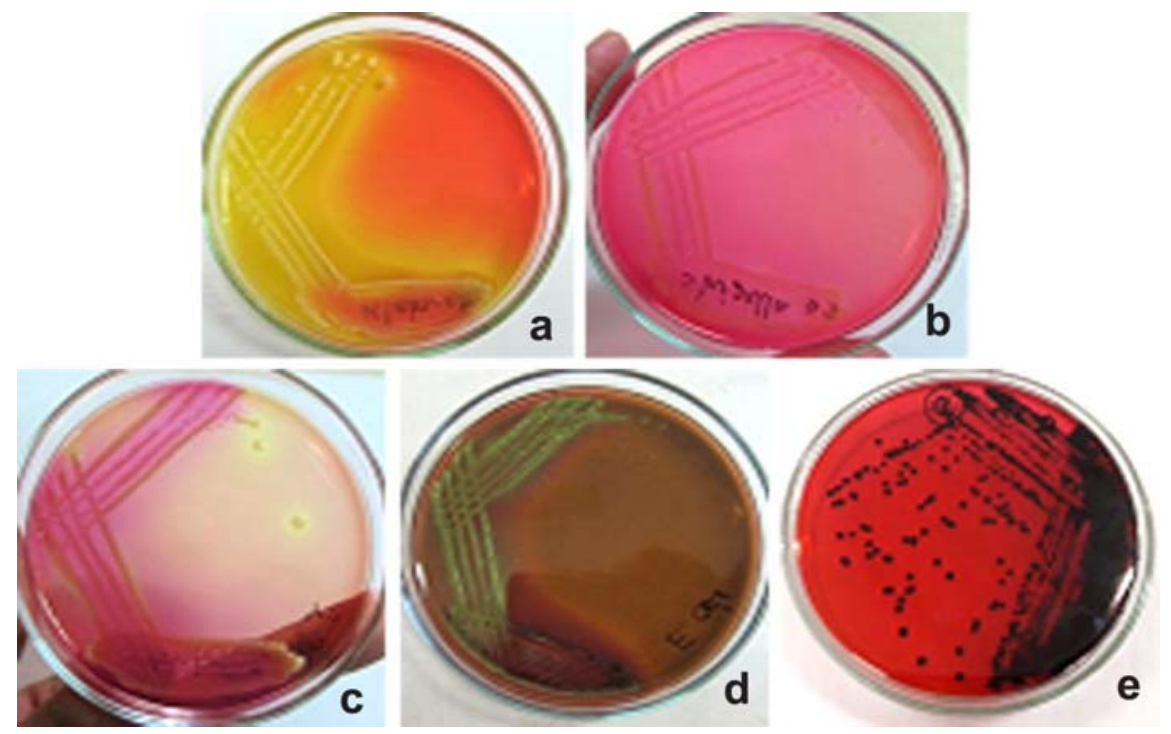

Fig. 2. Growth of representative bacterial isolates on different selective media. (a) Klebsiella spp. on XLD agar medium, (b) Shigella spp. on XLD agar medium, (c) Enterobacter spp. on XLD agar medium, (d) E. coli on EMB agar and (e) Salmonella on XLD agar.
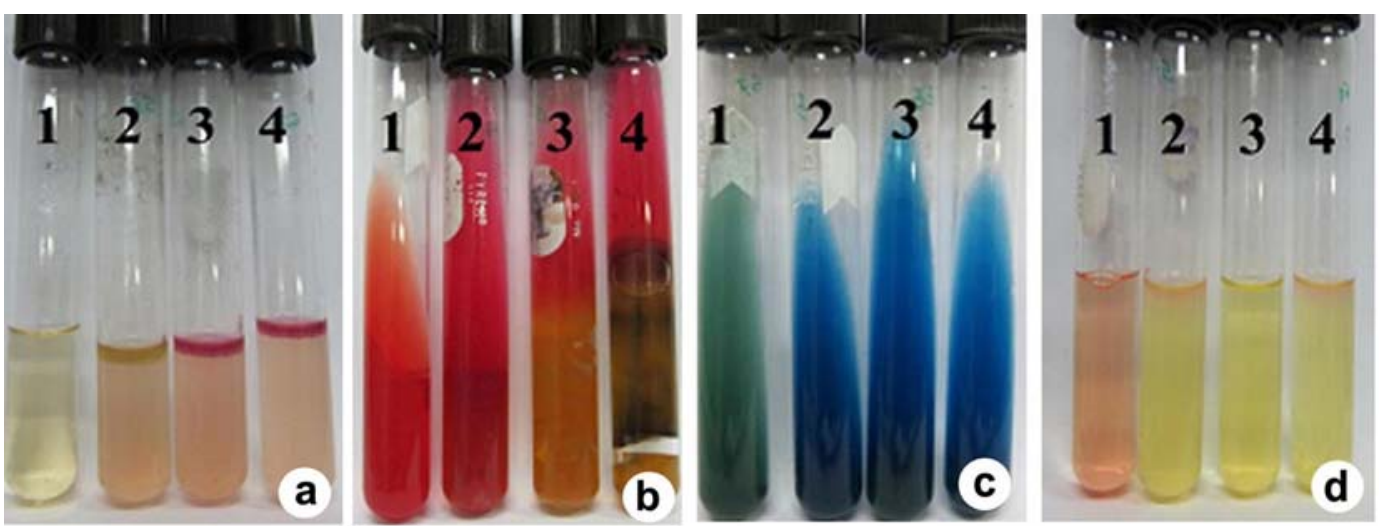

Fig. 3. Representative of biochemical tests used for identification of isolates. (a) Indole test: 1: Negative control; 2: Klebsiella spp.; 3: E. coli; 4: Shigella spp. (b) Kligler iron agar test: 1. Negative control; 2: Pseudomonas spp.; 3: Shigella spp; 4: Salmonella spp. (c) Citrate utilization test: 1: Negative control; 2: Pseudomonas spp.; 3: Shigella spp.; 4: Salmonella spp. (d) Urease test: 1. Negative control; 2: Pseudomonas spp.; 3: Shigella spp. and 4: Salmonella spp. 


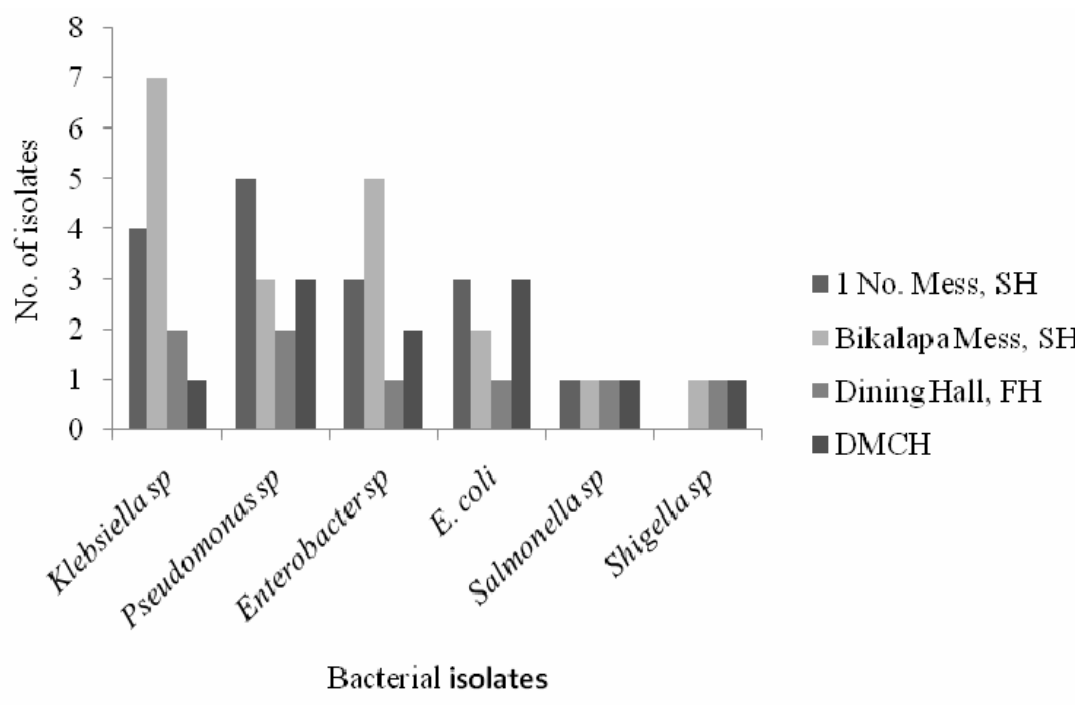

Fig. 4. Distribution of bacterial isolates in the various study areas.

The presence of cockroaches in an environment rich with pathogenic bacteria, like hospitals is highly dangerous as it might enable transmission of life threatening diseases. Presence of cockroaches carrying pathogenic bacteria in food-processing establishments is also alarming and imposes great threat to public health. These data also indicate to the lack of hygiene in hospitals and food processing areas in Dhaka.

This study suggests that the cockroach is potential source of transmission of life threatening diseases. Regular control of this pest by strict implementation of pest control regulations is mandatory in Bangladesh to ensure good public health.

\section{LITERATURE CITED}

BENNETT, G. 1993. Cockroaches as carriers of bacteria. Lancet 341(8847): 732.

BOASE, C.J. 1999. Trends in urban refuse disposal: A pest's perspective. Proceedings of the 3rd International Conference on Urban Pests Czech University of Agriculture, Prague, Czech Re ic,: 83-98.

BORROR, D.J., DELONG, D.M. and TRIPLEHORN, C.A. 1981. An introduction to the study of insects,

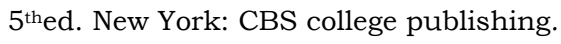

CHAICHANAWONGSAROJ, N., VANICHAYATANARAK, K., PIPATKULlACHAT, T., POLROJPANYA, M. and POLROJPANYA, M. 2004. Isolation of Gram-negative bacteria from cockroaches trapped from urban environment. Southeast Asian J. Trop. Med. Public Health 35(3): 681-684.

ClOAREC, A., RIVAUlT, C., FONTAINE, F. and LE GUYADER, A. 1992. Cockroaches as carriers of bacteria in multi-family dwellings. Epidemiol. Infect. 109(3): 483-490.

FOTEDAR, R., SHRINIWAS, U.B. and VERMA, A. 1991. Cockroaches (Blattella germanica) as carriers of microorganisms of medical importance in hospitals. Epidemiol. Infect. 107(1): 181-187. 
GUPTA, R. 1997. Description of the two species of nematodes of cockroaches (Periplaneta americana) reported from Nepal. Tribhuvan University Journal 20:25-30.

HAMID, K. and SHAHNAZ, K. 2012. Cockroaches [Periplaneta americana (L.), Orthoptera; Blattidae] as carriers of bacterial pathogens, Khorramshahr County, Iran Jundishapur J Microbiol. 5(1): 320-322.

IMMS, A.D. 1965. A General Textbook of Entomology, 9 $9^{\text {th }}$ ed. London. ELBS and Methuen Co. Ltd.

KABIR, S.H.M., QUAYUM, M.A. and HUDA, K.M.N. 1981. A Textbook of Zoology for Higher Secondary Class. Publisher S.M.H. Kabir, 20-G, Dhaka, Bangladesh.

KHRUSTALYOVA, N.A.1994."Epidemiological sanitary hygienic and medical significance of common cockroaches”. Byulleten, Mosko. Obs. Isp. Prir. Otd. Biologic. 99: 3-14.

LIN, Y.Z., CUI, Y.B., YANG, W., RAO, L.Y., PAN, W. and CHEN, J.L. 2008. Investigation on species composition of cockroaches and bacteria-carrying on their bodies in five cities of Hainan. Chin. J. Parasitol. Parasit. Dis. 26(1): 77-78.

OOTHUMAN, P., JEFFERY, J., AZIZ, A.H., BAKAR, A.E. and JEGATHESAN, M. 1989. Bacterial pathogens isolated from cockroaches trapped from pediatrics wards in peninsular Malaysia. Trans. R. Soc. Trop. Med. Hyg. 83(1): 133-5.

PAI, H.H., CHEN, W.C. and PENG, C.F. 2005. Isolation of bacteria with antibiotic resistance from household cockroaches (Periplaneta americana and Blattella germanica). Acta Trop. 93(3): 259265.

PELCZAR, M.J., CHAN, E.C.S. and KRIEG, N.R. 1993. Microbiology: Concept and Application International edition. McGraw-Hill, USA.

PAUL, S., KHAN, A.M., BAQUI, M.A. and MUHIBULLAH, M. 1992. Evaluation of the common cockroach Periplaneta americana (L.) as carrier of medically important bacteria. J. Commun. Dis. 24(4): 206-210.

RIVAULT, C., CLOAREC, A. and GUYADER L.A. 1993. Bacterial load of cockroaches in relation to urban environment. Epidemiol. Infect.110: 317-325.

SALEHZADEH, A., TAVACOL, P. and MAHJUB, H. 2007. Bacterial, fungal and parasitic contamination of cockroaches in public hospitals of Hamadan, Iran. J. Vect. Borne. Dis. 44: 105-110.

STEK, M. 1982. Cockroaches and enteric pathogens. Trans. R. Soc. Trop. Med. Hyg. 76: 566-617.

TACHBELE, E., ERKU, W., GEBRE-MICHAEL, T. and ASHENAFI, M. 2006. Cockroach-associated food-borne bacterial pathogens from some hospitals and restaurants in Addis Ababa, Ethiopia: Distribution and antibiograms. J. Rural and Tropical Public Health 5: 34-41.

TIlahun, B., WORKU, B., TACHBEle, E., TEREFE, S., KlOOS, H. and LEGESSE, W. 2012. High load of multi-drug resistant nosocomial neonatal pathogens carried by cockroaches in a neonatal intensive care unit at Tikur Anbessa specialized hospital, Addis Ababa, Ethiopia. Antimicro. Resis. Infec. Cont. 1: 12.

ZARCHI, A.A. and VATANI, H. 2009. A survey on species and prevalence rate of bacterial agents isolated from cockroaches in three hospitals. Vector Borne Zoonotic Dis. 9(2): 197-200. 